\title{
Административная юстиция как один из инструментов защиты прав граждан в отношениях с органами исполнительной власти
}

Морозова O.B. *

Дальнейшее развитие и реализация на практике института административной юстиции является насущной необходимостью для российской системы публичного права. Данный институт охватывает различные методы достижения баланса между осуществлением властных полномочий органами исполнительной власти и защитой лиц, чьи интересы и права при этом затрагиваются. Принимая во внимание недостаточный уровень развития административной юстиции в РФ, необходимо обратится к опыту зарубежных стран, где эти механизмы уже хорошо отлажены.

Ключевые слова: административная юстиция; административная юрисдикция; обжалование; административный суд; административный квазисудебный орган.

Права и свободы человека и гражданина являются в правовом государстве одним из центральнообразующих факторов, во многом определяя смысл, содержание и применение нормативных актов, деятельность государственных органов власти и местного самоуправления. Их защита, безусловно, должна обеспечиваться соответствующими правовыми инструментами. При этом выбор этих инструментов индивидуален для каждого государства и общества, первичная роль, однако, в большинстве стран была и остается у судебных органов. Как подчеркивал А.И. Елистратов, «одинаковое подчинение закону и суду ставит должностных лиц и граждан на общую юридическую плоскость» 1 .

В силу очевидного неравенства положения и возможностей участников административных правоотношений правовой статус частных лиц, в отличие от правового статуса административного органа подразумевает повышенный уровень защиты прав и свобод первых, на-

\footnotetext{
* Морозова Ольга Владимировна - аспирант кафедры Административного и финансового права МГИМО (У) МИД РФ. morozova.olga@inbox.ru.

1 Елистратов А.И. Должностное лицо и гражданин//Вопросы административного права. М., 1916. С. 80.
} 
рушение которых должно находить незамедлительную и действенную реакцию со стороны государства. В частности, в рамках судебного контроля за соблюдением прав и свобод человека и гражданина в деятельности администрации можно выделить институт судебного обжалования неправомерных действий (бездействия), решений администрации, известный как административная юстиция.

В разных государствах этот институт прошел довольно сложные и неоднозначные этапы своего становления. В результате в каждой стране в тот или иной момент времени создавались собственные институты зашиты прав граждан с учетом потребностей общественного и исторического развития.

В юридической науке принято выделять две основные системы административной юстиции, соответствующие существующему делению правовых систем на англосаксонскую и континентальную.

Первая система характеризуется отсутствием специально созданных административных судов (например, в Великобритании, США, Австралии, Новой Зеландии, Индии, Канаде), что не исключает, однако, в некоторых странах (например, в Великобритании, США, Австралии, Новой Зеландии) учреждения иных административных юрисдикций, например, административных трибуналов, которые по своей природе, компетенциям и порядку образования de facto являются административными судами, но не входят в судебную систему de jure.

Вторая система, наоборот, предполагает функционирование административных судов (во Франции, Германии, Италии, Австрии, Люксембурге, Финляндии, Швеции, Греции, Испании, Португалии, Болгарии, Польше, Чехии и др.) или палат по административным делам в рамках обычных судебных органов (в Швейцарии, Румынии, Латвии, Ираке, Китае). ${ }^{2}$.

Такое разделение сложилось исторически, в силу особо развитого внутреннего контроля за деятельностью администрации, в первом случае, и большего значения именно судебных органов - во втором.

Классический вариант формирования административной юстиции представляет собой французская модель, поскольку именно во Франции впервые возникла и была воплощена в жизнь идея создания специализированных учреждений по рассмотрению административноправовых жалоб. Создатели французской системы административной

2 Кривельская О.В. Механизм защиты прав граждан в административном процессе России и Германии // Право и безопасность. 2004, № 4 (13). 
юстиции исходили из необходимости максимального обособления исполнительной власти путем изъятия контроля за администрацией из сферы действия даже обычных судов. Этот контроль был возложен на созданный в 1800 г. Государственный совет ${ }^{3}$. В результате деятельности этого органа сложилась возглавляемая им система специальных судов (административных), разрешающая споры по жалобам граждан к органам управления и их должностным лицам и включающая:

- территориальные административные и апелляционные суды, а также:

- специализированные судебные учреждения (например, по вопросам социального обеспечения, Счетная палата, суды по делам ad hoc для каждого конкретного случая),

- дисциплинарные суды и др.

Современная концепция административной юстиции во Франции заключается в наделении органов, рассматривающих административно-правовые споры самостоятельным правовым статусом судебных учреждений административной юстиции, которые организационно и структурно отделены от публичной администрации и входят наряду с судами общей юрисдикции в судебную систему Франции. Суды общей юрисдикции (общегражданские суды) применяют частное право, а административные суды в своей деятельности руководствуются административным правом.

Общие принципы судопроизводства заложены в специальных законах, например, в Кодексе административной юстиции и дополняются судебной практикой.

Профессионализм и высокая квалификация судей именно в области административных споров достигается практикой откомандирования административных судей на работу в административные учреждения по специальности, тематике разбираемых административным судьей дел.

Помимо этого, для решения вопросов подведомственности дел судам общей юрисдикции или административным во Франции создан Трибунал (суд) по спорам о подведомственности, который наряду с разграничением компетенции судов отвечает на запросы граждан и предоставляет соответствующую информацию и разъяснения по этой тематике.

Французская идея административной юстиции вначале была скопирована в итальянском праве, а затем была модифицирована в Германии.

${ }^{3}$ См. подробнее: Брэбан Г. Французское административное право. М., 1988. 
В настоящее время в ФРГ в каждой земле действуют административные суды, которые могут рассматривать любые жалобы, имеющие административный характер (§ 40 ЗоАС). Деятельность административных судов регулируется Законом об административных судах от 31 января 1960 года (ЗоАС $)^{4}$ :

- в качестве первой инстанции действуют административные суды, где решения принимают палаты в составе трех судей-профессионалов и двух непрофессиональных судей (на общественных началах) (ЗоAC $\S 5$ ).

- в качестве второй инстанции административной юстиции выступает Высший административный суд (земельный), который принимает решения палатами, состоящими из трех профессиональных судей.

Суды первой и второй инстанции находятся в компетенции земель.

- центральным органом административной юстиции Германии выступает Федеральный административный суд. (принимает решения коллегией из пяти профессиональных судей (ЗоAC § 10). Его статус определен статьей 95 абзац 1 Основного Закона. Он рассматривается в качестве кассационной инстанции, но в редких случаях может быть и первой инстанцией (например, по делам с участием федеральных органов власти).

В качестве дополнительного инструмента защиты интересов частных лиц в рамках административных судов в Германии в Федеральном административном суде действует главный прокурор (ЗоAC § 35)

А при обычном и земельном административных судах действуют так называемые представители общественного интереса (ЗоАС § 36).

Обжалование решений административных судов производится в форме апелляции Высшим земельным административным судом, осуществляющим проверку фактических и правовых аспектов дела.

В качестве кассационной инстанции Высших земельных административных судов выступает Федеральный административный суд, который проверяет правовые обстоятельства дела.

В Германии действуют также специализированные административные суды (финансовые, суды по вопросам социального обеспечения, занимающиеся пенсиями и другими пособиями). Эти суды необходимы для более квалифицированного рассмотрения вопросов, связанных с узкой специализацией служащих администрации, а также для привлечения представителей общественности к участию в рассмотрении дел.

${ }^{4}$ Verwaltungsgerichtsordnung. (http://bundesrecht.juris.de/vwgo/index.html). 
В ФРГ административные суды обладают исключительно юрисдикционными полномочиями, в отличие от Государственного совета Франции, который наделен еще административными и консультативными функциями.

В Великобритании и США, относящихся к англо-саксонской системе права, защита субъективных прав граждан осуществляется во внесудебном порядке. При чем в Великобритании этот внесудебный порядок фактически приближен к судебному, то есть разбирательство проводится в административных трибуналах, чей правовой статус балансирует на грани органа исполнительной и судебной власти.

С одной стороны, административные трибуналы законодательно и структурно не входят в судебную систему Великобритании.

Но с другой стороны, функции, осуществляемые ими, непосредственно ход разбирательства по административным делам, а также независимость от органов исполнительной власти, подкрепляемая их внутренней структурой, компетенцией, свидетельствует о том, что это учреждения, выведенные за рамки исполнительного органа, и созданные именно как самостоятельная инстанция исключительно для рассмотрения жалоб граждан на действия и решения органов исполнительной власти, то есть по сути это административные суды, лишь формально не являющиеся таковыми.

Так, в Великобритании сейчас действуют около 60 видов административных трибуналов. Они функционируют на основе собственных статутов, которые определяют их количественный состав, процедуру деятельности. Следует отметить, что для органов административной юстиции Великобритании характерно отсутствие стройности и единства как материально-правовых, так и процедурных аспектов их деятельности. Обусловлено это тем, что каждый трибунал «закреплен» за министерством определенного профиля, устанавливающим для него свои организационно-процедурные правила. Таким образом, процедура рассмотрения дел в административных трибуналах, устанавливающаяся не законодательным органом, а министерством, разнится от трибунала к трибуналу, что, безусловно, создает дополнительные трудности и не дает в полной степени назвать этот орган независимым административным судом.

Для унификации этих правил был создан Совет по трибуналам, который наряду с этим является еще и консультативным органом для граждан. Его решения не носят обязательного характера, а его целью является помощь гражданам при направлении ими обращений в тот 
или иной трибунал (в том числе разъяснение вопросов порядка рассмотрения дел при обжаловании и т.д. $)^{5}$.

Нельзя не отметить, однако, и Закон «О трибуналах и расследованиях» в редакции 1992г, также унифицирующий деятельность административных трибуналов. Пункт 8 Закона 1992 года устанавливает, что полномочия соответствующих министров по разработке, одобрению и подтверждению процессуальных правил для трибунала могут быть реализованы только после консультации с Советом. Совет состоит не менее чем из 10 и не более чем из 15 членов, назначаемых Лордом-Канцлером и Лордом-Адвокатом. Один из членов Совета назначается председателем Совета.

Утверждение процессуальных норм деятельности трибуналов осуществляется различными субъектами -министрами, Лордом-канцлером после консультаций с Советом по трибуналам, либо даже самими трибуналами.

Обычно порядок и субъект утверждения правил деятельности трибуналов устанавливается в Законе о соответствующем виде деятельности. Например, нормы об Апелляционном трибунале по вопросам иммиграции и предоставления политического убежища содержатся в Акте о гражданстве, иммиграции и предоставлении политического убежища 2002 года, а об Апелляционном трибунале по вопросам занятости - в Акте о трибуналах по вопросам занятости 1996 года.

Трибуналы представляют собой специфическое британское явление. Г.И. Никеров рассматривает их как своеобразные «неформальные» суды. Они занимают промежуточное положение между администрацией и общими судами ${ }^{6}$, по своей природе фактически являясь судебными органами.

В США, относящихся, как и Великобритания, к англо-саксонской системе права, административная юстиция, по сути, является административной юрисдикцией, то есть защита от произвола органов исполнительной власти осуществляется специализированными учреждениями зачастую в рамках самого органа исполнительной власти. В США органы административной юстиции делятся на два вида:

1) Комитеты, отделы, апелляционные управления с возглавляющими их административными арбитрами в рамках самого органа

5 CS.H. Bailey. Cases, materials and commentaries on administrative law. London, Sweet\&Maxwell, 2005. P. ${ }^{\circ} 149$..

${ }^{6}$ См: Никеров Г.И. Административно-процессуальное право США //ГиП. 1997. № 12. 
исполнительной власти, решения и действия которого обжалуются. Административные арбитры (судьи) при этом назначаются руководителем исполнительного органа. Таким образом, обжалование происходит в рамках данного исполнительного органа, что, с одной стороны, ставит вопрос о его независимости, так как административные учреждения по сути являются судьей в своем собственном деле, но с другой стороны способствует более компетентному рассмотрению дела. Орган исполнительной власти при этом фактически совмещает свои основные функции с судебными функциями.

2) Самостоятельные по отношению к этому органу исполнительной власти административные учреждения, осуществляющие исключительно квазисудебные функции. В частности, Комиссии штатов по выплате компенсаций трудящимся.

3) Такие квазисудебные органы нередко проходят дополнительные стадии развития и трансформируются в самые настоящие административные суды, входящие в судебную систему. В качестве примера можно привести:

- Налоговый суд, который изначально являлся Апелляционным налоговым управлением, входящим в состав Департамента казначейства, и

- Претензионный суд, который создавался в 1855 году как обычное административное учреждение, чьей основной функцией являлся сбор материалов по претензиям частных лиц, их анализ и передача Конгрессу со своими рекомендациями для решения Конгрессом обозначенных проблем. В 1863 году данный Суд получил полномочия по самостоятельному вынесению таких решений путем издания нормативных актов по существу предъявляемых претензий. Практически через 100 лет Верховный суд США объявил Претензионный суд полноправным судебным органом.

Порядок деятельности вышеперечисленных квазисудебных органов регулируется ЗАП 1946 года, инкорпорированном в $\S$ 551-59. 701-06. 1305. 3105. 3344. 5372. 7521 Свода законов США (Code of U.S.) 7 . Законодательное закрепление процессуальных норм о деятельности органов административной юстиции осуществляется и на уровне штатов, где по федеральному образцу приняты Законы о процедурах, которые также в себя включают и регулирование вопросов административного судопроизводства.

${ }_{7}^{7}$ Administrative procedure Act - 5 USA. - (http//iresist.com/ice/ Administrative procedure Act - 5 USA). 
Действие ЗАП 1946 года не распространяется (за исключением требования обнародовать принятые нормы и решения) на специализированные органы по рассмотрению споров, созданные из представителей сторон или представителей организаций сторон, на военные суды и военные комиссии, военные органы власти, действующие в военное время на оккупированной территории.

Стоит отметить достойный заимствования публичный характер деятельности квазисудебных органов, реализующийся в обязанности квазисудебного органа обеспечивать доступ общественности ко всем своим решениям (п. b статьи 3 ЗАП (§ 552 Свода законов США)).

ЗАП США гарантируют лицам, не согласным с решением учреждения, право на его обжалование в специальное апелляционное управление внутри этого учреждения, а затем в суд общей юрисдикции (районные федеральные суды) либо в отдельных случаях прямо в суд (например, в случаях:

- если прохождение всех досудебных инстанций нанесет лицу непоправимый ущерб;

- если учреждение явно действует вне сферы своей компетенции;

- если уже известно мнение администрации по аналогичным делам и частное лицо с ним принципиально несогласно;

- если разбирательство дела требует решение вопроса права, то есть насколько верно публичная администрация истолковывает и применяет нормы права) $)^{8}$.

Если же рассматриваются вопросы факта, то досудебный порядок является обязательным. Однако на практике зачастую тяжело разделить вопросы права и факта, поэтому по сложившейся практике административное учреждение (административный трибунал) рассматривает дело первым.

Такой развитый досудебный порядок, безусловно, несет в себе как положительные, так и негативные стороны. К очевидным преимуществам можно отнести:

- оперативность разрешения дел;

- низкую формализацию процесса рассмотрения дел;

- дешевизну.

- при этом административные судьи активно взаимодействуют с должностными лицами административных учреждений, что повышает качество рассмотрения дел.

${ }^{8}$ CM.: Alfred C. Aman, Jr. \& William T. Mayton. Hornbook on Administrative Law. West, $1993, \S 13.7$. 
Среди минусов можно отметить:

- множественность независимых агентств США и трибуналов Великобритании;

- сложность понимания юридической природы и взаимосвязи между трибуналом, агентством и органом управления;

- узкоспециализированный характер органов административной юстиции.

Данные квазиадминистративные суды находятся в рамках административных учреждений, и поэтому не могут быть абсолютно независимы от органов исполнительной власти (об этом свидетельствует и порядок назначения административных судей, председателей административных трибуналов).

В США Закон 1946 года, который всеобъемлюще регулирует не только процедурную деятельность органов исполнительной власти, но и обжалование этой деятельности в вышестоящий или специально созданный орган в рамках самой исполнительной власти и, более того, порядок обжалования в суд, что способствует большей доступности понимания для граждан всех этих трех видов деятельности.

Опыт зарубежных стран представляет большой теоретический и практический интерес. Выбор той или иной формы административной юстиции в каждой из стран обусловлен особенностями исторического развития, традициями правовой системы, государственного устройства и публичной службы и не лишен как достоинств, так и недостатков. Поэтому перенос одной из действующих схем, в том виде, в каком они функционируют в этих странах, нецелесообразен и малоэффективен.

Выбирая модель построения административной юстиции в России, следует принимать во внимание множество факторов, всю специфику экономического, политического и исторического развития, уровень правовой культуры и готовность к тем или иным новациям.

\section{Библиографический список}

Бахрах Д.Н. Административное судопроизводство, административная юстиция и административный процесс // Государство и право. 2005, № 2.

Брэбан Г. Французское административное право. М., 1988.

Елистратов А.И. Должностное лицо и гражданин // Вопросы административного права. М., 1916. 
Демин А.А. Суды административной юстиции: Сравнительный анализ зарубежного опыта // Вестник МГУ. Серия 11. «Право». 1994. № 1.

Зеленцов А.Б. Контроль за деятельностью исполнительной власти в зарубежных странах: Учебное пособие. М.: Изд-во РУДН, 2002.

Кривельская О.В. Механизм защиты прав граждан в административном процессе России и Германии // Право и безопасность. 2004, № 4 (13).

Лафитский В. Административная юстиция в США // Конституционное Право: Восточноевропейское Обозрение. 2003. № 1.

Никеров Г.И. Административно-процессуальное право США //Государство и право. 1997, № 12.

Старилов Ю.Н. Административная юстиция: Проблемы теории. Воронеж: Изд-во ВГУ, 1998.

Сунгуров А., Маччелли Д., Абросимова Е., Виноградова Т. Механизмы контроля над деятельностью публичной администрации в странах Европы // Сравнительное конституционное обозрение. 2007, № 1.

Тимошенко Н.Г. Административная юстиция в Великобритании // Журнал российского права. 1997, № 5.

Хаманева М.Ю. Административная юстиция в США. // Государство и право, 1993, № 3 .

S.H. Bailey. Cases, materials and commentaries on administrative law. London, Sweet\&Maxwell, 2005

\section{Administrative Justice as an Instrument of Citizens Rights Protection against Administrative Authorities (Summary)}

\section{Olga V. Morozova*}

The proper realisation of an idea of administrative justice is a pressing need to the Russian public law system. It embraces all the mechanisms designed to achieve a proper balance between the exercise of public power by the administrative institutions and those affected by the exercise of that power. Considering the insufficient level of its development in Russia, one should refer to the foreign experience of the countries, where such mechanisms are already well-adjusted.

Keywords: administrative justice; administrative jurisdiction; appeal; administrative court; quasi-judicial tribunal.

\footnotetext{
* Olga V. Morozova - post-graduate student of the Chair of Administrative and Financial law, MGIMO-University MFA Russia. morozova.olga@inbox.ru.
} 